\title{
Grebeg Sudiro dan Representasi Keberagaman di Sudiroprajan, Kota Surakarta
}

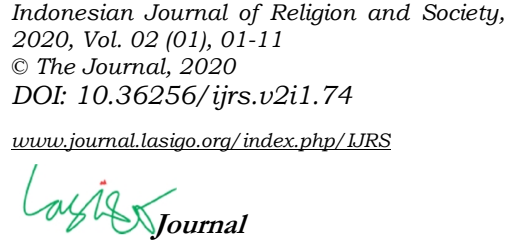

Article History

Received: November, 11 th 2019

Revised: April, 24th 2020

Accepted: May, $9^{\text {th }} 2020$

\section{Latifa Dinar Rahmani Hakim}

Departemen Sosiologi, FISIP Universtas Indonesia, Depok, Jawa Barat, Indonesia

rlatifadinar@gmail.com

\begin{abstract}
Several studies stated the role of government is one of the keys that influence success in overcoming diversity in a plural society. Through the case study in Sudiroprajan village, this study aims to explain the success of overcoming the problem of diversity not only because of the role of the government, but through community involvement. Using a qualitative approach, the results of this study show that the Sudiroprajan community collective awareness is an effective way to overcome the problem of diversity that has the potential to cause conflict. Collective awareness is built through socio-economic similarity, historical experience, needs and acceptance, interaction and negotiation. The building of collective awareness in the Sudiroprajan community is able to produce diversity products in the form of the Grebeg Sudiro tradition. The Grebeg Sudiro tradition has become a symbol of the Sudiroprajan village diversity as well as a medium of diversity for people outside the village.
\end{abstract}

Keywords: Diversity, Collective Consciousness, Grebeg Sudiro, Sudiroprajan

\begin{abstract}
ABSTRAK
Banyak studi mengatakan bahwa peran pemerintah menjadi salah satu kunci yang mempengaruhi keberhasilan dalam mengatasi keberagaman pada masyarakat plural. Melalui kasus pada kampung Sudiroprajan, penelitian ini bertujuan untuk menjelaskan keberhasilan mengatasi masalah keberagaman tidak hanya karena peran pemerintah, namun melalui keterlibatan masyarakat. Dengan menggunakan pendekatan kualitatif, hasil penelitian menunjukkan bahwa kesadaran kolektif masyarakat Sudiroprajan merupakan cara efektif untuk mengatasi masalah keberagaman yang berpotensi memunculkan konflik. Kesadaran kolektif terbangun melalui kesamaan sosial-ekonomi, pengalaman sejarah, kebutuhan dan penerimaan, interaksi serta negosiasi. Terbangunnya kesadaran kolektif pada masyarakat Sudiroprajan mampu menghasilkan produk keberagaman berupa tradisi Grebeg Sudiro. Tradisi Grebeg Sudiro telah menjadi simbol keberagaman kampung Sudiroprajan sekaligus media keberagaman bagi masyarakat di luar kampung.
\end{abstract}

Kata Kunci: Keberagaman, Kesadaran Kolektif, Grebeg Sudiro, Sudiroprajan

\section{Pendahuluan}

Indonesia merupakan salah satu negara majemuk karena keanekaragaman masyarakat dan budayanya. Keberadaan berbagai kelompok budaya, etnis, dan agama ini sering kali disebut dengan masyarakat multikultur (Kumbara, 2009). Sebagai negara multikultur, Indonesia mempunyai lebih dari 17.000 pulau, 1.340 suku bangsa, dan 600 jenis bahasa

Corresponding Author

Name : Latifa Dinar Rahmani Hakim

Email : rlatifadinar@gmail.com 
(Kasturi, 2014). Keragaman tersebut diikat dalam sebuah prinsip kesatuan dan persatuan yang dikenal dengan istilah Bhineka Tunggal Ika. Bhineka Tunggal Ika tersebut menjadi simbol negara kesatuan untuk mewujudkan kehidupan bangsa yang adil dan sejahtera (Budiarti \& Effendy, 2009). Namun sebaliknya, ketika perbedaan dalam masyarakat multikultur tersebut tidak dikelola dengan baik, keberagaman tersebut akan menjadi ancaman dan potensi besar pada konflik (Firdaus, Yasin, \& Anggreta, 2015).

Keberagaman sendiri telah banyak ditelaah sebagai alternatif untuk menjaga kesatuan dan integrasi nasional (Syaifuddin, 2006). Secara umum keberagaman di Indonesia memberikan gambaran mengenai perbedaan dan toleransi antar sesama (Firdaus, Anggreta, $\&$ Yasin, 2020). Hal tersebut tidak jarang tercermin dalam kebijakan-kebijakan pemerintah yang digunakan untuk melindungi dan menyetarakan keberagaman (Shahab, 2004). Pemerintah dalam hal ini turut memberi jaminan dan mendorong terciptanya kebersamaan berdasar pada prinsip-prinsip multikulturalisme. Keberagaman dipandang sebagai sebuah solusi untuk mengakomodasi perbedaan dengan cara yang adil, namun di satu sisi juga dapat menimbulkan konflik jika tidak dapat diatasi dengan bijak (Verkuyten, 2005).

Mengelola masyarakat multikultur dengan keberagaman yang ada bukanlah suatu perkara mudah karena cenderung memunculkan konflik di dalamnya. Hal ini terjadi seiring dengan adanya upaya masing-masing kelompok untuk mempertahankan eksistensi budaya mereka dan kepentingan lain di dalamnya (Ma'mun, 2005). Melalui penyikapan yang tepat, kecenderungan konflik dapat diminimalisir. Adapun hal ini dapat disikapi dengan memanfaatkan segala peluang keberagaman yang ada di dalamnya. Peluang ini dapat mengubah potensi konflik dan kerapuhan sosial dalam masyarakat plural menjadi kekuatan untuk membangun identitas bersama (Setyaningrum, 2003).

Sebagai kota kota yang multikultur Surakarta merupakan kota yang rentan akan konflik. Proses Surakarta menjadi kota dengan masyarakat yang multikultur tentu tidak dapat ditempuh dalam waktu singkat. Surakarta sendiri telah lama menjadi hunian bagi berbagai macam kelompok etnis yang berawal dari maraknya jalur perdagangan pada masa kolonial dan menjadikannya kerap didatangi berbagai kelompok etnis dan suku seperti Tionghoa, Arab, Tamil (India), Madura, dan lain sebagainya (Joebagio, 2017). Dari berbagai kelompok etnis yang menetap di Surakarta tersebut, interaksi antara Tionghoa dan Jawa adalah yang paling menonjol. Serangkaian konflik dan perselisihan antara Tionghoa dan Jawa di Surkarta kerap mewarnai relasi kedua kelompok etnis ini. Tidak jarang pula memunculkan stereotype dan persepsi buruk terhadap masing-masing kelompok etnis (Prihartanti \& Thoyibi, 2009). Meski demikian, terdapat satu kawasan di Surakarta yang mampu mengelola keberagaman menjadi sebuah peluang yaitu kampung Sudiroprajan.

Sudiroprajan dihuni oleh dua kelompok etnis, yakni Tionghoa dan Jawa yang hidup berdampingan. Hubungan baik dari kedua etnis ini terjalin sejak pemerintahan kolonial Belanda. Hingga saat ini, hubungan tersebut masih terjaga dengan baik dalam kehidupan sehari-hari seperti acara kelahiran, gotong royong, serta kegiatan keagamaan (Widyaningsih, 2007). Tidak seperti keberagaman secara umum yang melibatkan peran pemerintah, keharmonisan di kampung Sudiroprajan tidak melalui intervensi pemerintah melainkan atas kesadaran dari masyarakat itu sendiri. Hal ini yang mampu melanggengkan keharmonisan dalam keberagaman di Sudiroprajan, dan masyarakat terhindar dari adanya konflik yang mampu memecah belah kedua kelompok. Tulisan ini membahas mengenai bagaimana keharmonisan tercipta di kampung Sudiroprajan terbentuk dan bagaimana kesadaran kolektif masyarakat mampu menghasilkan tradisi Grebeg Sudiro.

\section{Kerangka Teori}

Multikulturalisme, sebuah kebijakan yang pertama kali diperkenalkan di Amerika Serikat pada tahun 1960, merupakan perubahan signifikan dalam cara identitas dibangun dalam modernitas barat (Hoon, 2006:153). Kebijakan ini pada dasarnya merupakan arahan untuk penguatan identitas etnis. Secara terminologis, multikulturalisme merujuk pada dua hal berbeda yakni realitas (praktik) dan etika (ajaran). Realitas (praktik) dipahami sebagai interaksi produktif di antara elemen sosial yang beragam dalam sebuah tatanan kehiduapan sosial berkelanjutan. Sementara etika (ajaran) mengacu pada spirit, etos dan optimisme terhadap keragaman untuk dikelola dalam ranah publik. Multikulturalisme secara umum berasal dari kata multi (plural) dan kultural (budaya) yang mencakup keragaman seperti suku, ras, agama, atau subkultur dalam masyarakat. Multikulturalisme seringkali digunakan untuk menggambarkan masyarakat dalam negara yang mempunyai berbagai kelompok budaya berbeda dan biasanya berasal dari imigrasi (Liliweri, 2005). 
Multikulturalisme sebagaimana dijelaskan Hoon (2006) lebih menekankan pada aspek perbedaan dibandingkan kesamaan. Inti dari diskursus multikulturalisme sebenarnya adalah politik pengakuan dengan upaya menumbangkan budaya homogen melalui konstruksi identitas dan representasi budaya. Multikulturalisme seringkali dianggap mewakili budaya minoritas karena mampu menghadirkan beberapa aspek dari bentuk budaya-budaya tertentu. Terdapat dua poin penting dalam membahas multikulturalisme, yakni keragaman budaya dan politik pengakuan (Neumannova, 2007). Multikulturalisme secara politis merupakan kebijakan terhadap keberagaman dengan latar belakang identitas kolektif berupa etnis, agama, ataupun ras dalam suatu negara bangsa. Multikulturalisme sebagai kebijakan politik tercermin dalam peran pemerintah di mana mereka menyediakan dan menjamin adanya kesetaraan tanpa pengecualian (Kymlicka, 2012). Peran pemerintah ini juga terlihat dalam institusi, hukum serta tindakan yang memberikan pengakuan terhadap perbedaan budaya dalam ruang-ruang publik (Kusumadewi, 2010).

Multikulturalisme dalam pandangan Rosado (1996) menjelaskan bahwa individu atau kelompok dalam masyarakat bukan hanya mengakui dan menghormati perbedaan, namun juga membuka ruang untuk berkontribusi, sehingga menciptakan kultur yang inklusif. Dalam konteks ini masyarakat diberdayakan secara positif untuk mencapai keharmonisan. Rosado turut menjelaskan multikulturalisme ini sendiri dapat diterapkan dalam kebiasaankebiasaan masyarakat seperti adat istiadat, gaya berkomunikasi dan lain sebagainya. Oleh karenanya, relasi antar kelompok etnis atau budaya sangat diperlukan agar seimbang.

\section{Metode Penelitian}

Penelitian ini dilakukan secara kualitatif dengan pendekatan studi kasus. Adapun unit analisa dalam penelitian ini adalah kelompok Sudiroprajan di Surakarta. Penelitian ini melibatkan 9 orang informan yang dibagi menjadi tiga kategori, yakni kategori kelompok Jawa, kelompok Tionghoa (dalam kampung), kelompok Tionghoa (pinggiran). Penetapan kategori tersebut dilakukan dengan pertimbangan kecukupan data yang diperoleh dan efektifitas waktu.

Tabel 1. Kategori dan Kriteria Informan

\begin{tabular}{|c|c|c|c|}
\hline Kategori & Status & Kriteria & Jumlah \\
\hline \multirow{7}{*}{$\begin{array}{l}\text { Informan } \\
\text { Kelompok } \\
\text { Jawa }\end{array}$} & Tokoh & 1. Berasal dari kelompok etnis Jawa. Mempunyai & 3 orang \\
\hline & Masyarakat/A & kedudukan dan peran dalam kelompoknya & \\
\hline & gama & 2. Tinggal dan besar di kampung Sudiroprajan & \\
\hline & & $\begin{array}{l}\text { 3. Mempunyai pengetahuan mengenai sejarah dan } \\
\text { dinamika kampung Sudiroprajan }\end{array}$ & \\
\hline & Warga Umum & 1. Pernah atau sedang tinggal di kampung Sudiroprajan & 2 orang \\
\hline & & 2. Mengetahui dinamika kampung sudiroprajan & \\
\hline & & $\begin{array}{l}\text { 3. Memiliki pengalaman dan pengetahuan mengenai tradisi } \\
\text { grebeg sudiro }\end{array}$ & \\
\hline \multirow{5}{*}{$\begin{array}{l}\text { Informan } \\
\text { Kelompok } \\
\text { Tionghoa } \\
\text { (dalam) }\end{array}$} & Tokoh & 1. Berasal dari kelompok Tionghoa (dalam) dan mempunyai & 2 orang \\
\hline & Masyrakat & peran atau kedudukan dalam kelompoknya & \\
\hline & & 2. Tinggal dan besar di kampung Sudiroprajan & \\
\hline & & $\begin{array}{l}\text { 3. Mempunyai pengetahuan mengenai sejarah dan } \\
\text { dinamika kampung Sudiroprajan }\end{array}$ & \\
\hline & Warga Umum & $\begin{array}{l}\text { Pernah atau sedang tinggal dan mampu menceritakan } \\
\text { pengalaman selama tinggal di kampung Sudiroprajan serta } \\
\text { mengerti mengenai Grebeg Sudiro }\end{array}$ & 1 orang \\
\hline Informan & Tokoh & Berasal dari kelompok Tionghoa (pinggiran). Mempunyai & 1 orang \\
\hline Kelompok & Masyarakat/ & peran atau kedudukan baik di kampung atau kelompoknya. & \\
\hline $\begin{array}{l}\text { Tionghoa } \\
\text { (pinggiran) }\end{array}$ & Agama & $\begin{array}{l}\text { Mempunyai pengetahuan mengenai dinamika kampung dan } \\
\text { grebeg sudiro }\end{array}$ & \\
\hline
\end{tabular}

Peneliti dalam hal ini tidak dapat bersandar pada satu sumber data saja, namun dibutuhkan berbagai macam data baik dari wawancara dengan informan, observasi, studi terhadap dokumen pendukung seperti koran, buku, laporan-laporan dan lain sebagainya. Pengumpulan data dalam penelitian mengacu pada Creswell yang memberikan beberapa proses seperti melakukan observasi, wawancara dan studi dokumen (Creswell, 2015). Penelitian diawali dengan melakukan observasi di Kelurahan Sudiroprajan. Observasi dilakukan dengan mencari informasi mengenai kelompok Sudiroprajan. Selain itu observasi 
dijadikan jembatan untuk membangun relasi dalam mendapatkan informasi atau data yang relevan. Tahap kedua adalah wawancara. Wawancara dilakukan melalui dua bentuk, yakni terstruktur dan tidak terstruktur. Wawancara pada kelompok Sudiroprajan menggunakan pedoman wawancara agar tetap fokus pada hasil temuan yang diharapkan. Terakhir adalah dengan studi dokumen. Studi dokumen digunakan untuk melengkapi data yang diperoleh dari hasil wawancara dan observasi.

Setelah pengumpulan data selesai dilakukan, tahap selanjutnya dilakukan analisis terhadap data yang diperoleh. Analisis dan validasi diperlukan sebagai kekuatan untuk memperkuat serta mendapatkan akurasi dalam penelitian. Salah satu strategi yang dilakukan dalam tahap validasi adalah melakukan triangulasi sumber data. Hal ini dilakukan dengan cara menguji kembali data-data yang telah diperoleh dari beberapa informan berbeda (Creswell, 2015).

\section{Sudiroprajan: Ruang Keberagaman}

Sudiroprajan atau yang lebih dikenal dengan kampung pecinan terletak di sekitaran kali pepe dan Pasar Gede Surakarta. Meski dikenal sebagai kampung pecinaan, Sudiroprajan sendiri dihuni oleh dua kelompok etnis berbeda, yakni Tionghoa dan Jawa yang hidup berdampingan. Meleburnya kedua etnis hingga mampu hidup berdampingan ini tidak terlepas dari sejarah panjang perjalanan keduanya dalam membangun relasi sosial. Menelisik sejarah yang ada, Tionghoa pada awalnya datang ke Hindia Belanda (penyebutan Indonesia kala itu) sekitar abad ke-15 untuk melakukan perdagangan (Budiarti \& Effendy, 2009b). Seiring dengan perkembangannya, banyak imigran dari negeri Cina yang mulai berdatangan dan memuncak sekitar abad ke-19. Para imigran ini turut membawa kekayaan, potensi, dan budaya yang mereka miliki.

Potensi dari kelompok Tionghoa ini lebih mengarah pada kegiatan ekonomi. Lewat kegiatan ekonomi, beberapa kelompok etnis secara tidak langsung dipaksa untuk berpartisipasi aktif dalam aktifitas berdagang. Kelompok Tionghoa turut berinteraksi dengan kelompok etnis lain seperti Jawa, Madura, Banjar, Bali, Arab dan India (Nugroho, 2011). Maraknya perdagangan kala itu membuat beberapa kelompok Tionghoa memutuskan untuk menetap dan bermukim di sekitaran tempat berdagang. Pada masa kolonial, pemerintah Belanda turut membagi hunian di Surakarta berdasar kewarganegaraan. Pembagian hunian ini seperti halnya kelompok Arab di Pasar Kliwon, kelompok Eropa di Lojiwetan dan kelompok Tionghoa di kawasan Pecinaan sekitar Pasar Gede (Juwono, 1999).

Di bawah pemerintahan Belanda, kampung Sudiroprajan menjadi tempat bermukim etnis Tionghoa yang dipimpin oleh seorang pemimpin dengan sebutan Babah Mayor. Babah Mayor bertugas sebagai perantara yang menghubungkan orang-orang Tionghoa dengan pemerintah kolonial dalam berbagai macam kepentingan kala itu. Pada masa ini pula orang-orang Tionghoa di Sudioprajan diharuskan untuk melakukan adat istiadat yang mereka miliki, sehingga identitas mereka masih terjaga. Namun seiring berjalannya waktu, tradisi yang ada mulai ditinggalkan atau bahkan bercampur dengan tradisi masyarakat Jawa. Dalam perkembangannya, pembagian hunian secara tidak langsung mengakibatkan segregasi antara etnik yang satu dengan kelompok etnik lainnya. Meski demikian, hal ini tidak berlaku di Kawasan pecinaan. Sebelum terbentuk pemukiman China (pecinaan) di Sudiroprajan, sekitaran kawasan tersebut sudah dihuni terlebih dahulu oleh beberapa masyarakat Jawa meski jumlahnya tidak banyak. Sebagaimana dijelaskan oleh informan L (wawancara 9 September, 2019), mereka yang tinggal di kawasan tersebut merupakan abdi dalem dan para selir dari Kraton Kasunanan Surakarta. Karena posisi hunian yang berdekatan dan tidak memiliki jarak, kedua kelompok ini mulai berinteraksi dan membangun hubungan baik, sehingga memunculkan hubungan sosial dan pertukaran budaya. Melalui interaksi dan hubungan sosial tersebut mulai terjadi pembauran antara kelompok etnis Tionghoa dan Jawa.

Meski tercatat dalam sejarah bahwa Surakarta pernah menjadi tempat konflik yang melibatkan kelompok Tionghoa, namun hal ini tidak mempengaruhi interaksi sosial dan hubungan yang harmonis di antara kedua etnis tersebut (Riyadi, Aji, \& Hermawan, 2017). Benny Juwono (1999) menyebutkan bahwa terdapat tiga faktor yang memperkuat interaksi antar kedua kelompok etnis ini. Faktor tersebut adalah adanya sejarah pembentukan kampung di mana kedua kelompok etnis tinggal bersama karena mempunyai kesamaan ekonomi, adanya kesadaran untuk menciptakan harmoni sosial dengan saling toleransi, dan 3). Adanya semangat nasionalisme yang sama. 


\section{Tantangan Keberagaman di Sudiroprajan}

Surakarta pada awal abad ke 20 menjadi kawasan yang multirasial, multikultural, dan multiagama/kepercayaan. Seiring berkembangnya kota, maka semakin banyak pula kemajuan baik dalam bidang kesenian, teknologi, dan sarana prasarana (Kuntowijoyo, 2006). Namun berkembangnya kota tidak bisa dilepaskan dari adanya konflik terutama mengingat kondisi masyarakat Surakarta yang beragam dan sangat rentan terhadap konflik khususnya mengarah pada segmentasi rasial (Riyadi et al., 2017).

Konflik di Surakarta tentunya tidak dapat dilepaskan dari peristiwa masa Orde Baru. Peristiwa tersebut dikenal dengan peristiwa '98 yang merupakan salah satu peristiwa kelam di Surakarta. Banyak korban kekerasan dan penjarahan dari adanya peristiwa tersebut khususnya bagi kelompok Tionghoa. Pada tahun kerusuhan Mei 1998. Tanggal 14-15 Mei, terjadi pembakaran dan pengerusakan rumah-rumah penduduk serta fasilitas-fasilitas umum (Baidhawy, 2010). Kejadian ini sempat menyebabkan kota Surakarta lumpuh selama beberapa hari. Berbagai bangunan yang terdapat di pusat kota menjadi sasaran anarki massa. Hal ini terlihat pada kantor, bank, serta kawasan pertokoan seperti Matahari Beteng yang menjadi incaran pengrusakan dan penjarahan massa (Putro, Atmaja, \& Sodiq, 2017).

Kondisi Surakarta kala itu diperpanas dengan adanya pernyataan sebagai kota sumbu pendek. Meski demikian, pada praktiknya konflik yang ada selalu diakhiri dengan resolusi cepat. Terdapat hal menarik dari adanya perisitiwa ini. Secara umum peristiwa ini sangat identik dengan kelompok Tionghoa sebagai korban. Meski demikian, masyarakat Sudiroprajan yang sebagian besar terdiri dari orang-orang Tionghoa justru tidak terkena dampak dari peristiwa tersebut. Bahkan kawasan ini dapat dikatakan aman. Hal ini turut disampaikan oleh beberapa masyarakat yang menjadi saksi kejadian tersebut.

"pada waktu periwistiwa '98 itu daerah sini sangat aman, bahkan bisa dibilang tidak ada satupun batu terlempar mengenai tempat ini. Masyarakat disini saling menjaga satu sama lain. Mereka (Jawa) turut berjaga di depan, mencegah para penjarah biar gak masuk" (Wawancara A, Tokoh Agama, 12 September 2019).

Kerusuhan yang ditujukan kepada orang-orang Tionghoa menjadi hal ironis, karena pada realitasnya orang-orang Tionghoa sebenarnya mempunyai peran penting dalam pengembangan kebudayaan Jawa. Hal ini terlihat pada kultur keseharian orang Tionghoa di Sudiroprajan yang menunjukkan sikap masyarakat yang terbuka, tidak ekslusif dan mampu berbaur secara alamiah. Bahkan dalam situasi konflik rasial yang melibatkan orang Tionghoa dengan orang Jawapun, masyarakat Sudiroprajan tidak pernah tersentuh konflik sentimen rasial. Ketika konflik terjadi, masyarakat Jawa mencoba melindungi orang-orang Tionghoa. Beberapa warga turut mengisahkan banyak masyarakat Tionghoa yang mempunyai kerabat jauh juga turut mengungsi dan tinggal di Sudiroprajan hingga kekacauan mereda. Masyarakat Jawa kala itu berjaga dan turun ke jalan mengamankan keadaan. Melalui kejadian kejadian tersebut, relasi antar kedua etnis semakin membaik khusunya dengan kelompok Tionghoa yang tinggal di pinggiran jalan.

"Waktu kejadian rusuh waktu itu, kami di sini orang-orang Jawa pasang badan melindungi teman-teman Tionghoa. Lucunya, dulu kami ada yang sampai pakai baju kayak mau perang itu. Dan pas itu kerabat-kerabat dari warga Tionghoa pada datang. Kampung ini jadi ramai kala itu karna mereka (perusuh) tidak bisa menjangkau" (Wawancara R, tokoh masyarakat, 10 September 2019).

Kelompok Tionghoa di kampung Sudiroprajan sendiri jika dilihat polanya terbagi menjadi dua bagian, yakni yang tinggal di dalam kampung dan yang tinggal di pinggiran jalan raya. Pada awalnya, hubungan dengan masyarakat yang tinggal di pinggiran jalan raya memang dapat dikatakan kurang harmonis. Hal ini dikarenakan banyak dari mereka yang sibuk mengurusi pekerjaannya sebagai wirausahawan. Mereka cenderung membatasi ruang gerak kepada masyarakat yang tinggal di dalam kampung. Hal ini menjadi tantangan tersendiri bagi masyarakat. Pada awalnya pun kebanyakan dari mereka terlibat secara pasif dalam kegaiatan masyarakat. Namun dengan adanya peristiwa '98, sekan menjadi titik balik hubungan diantara keduanya. Kelompok Tionghoa mulai membuka ruang baru dan meruntuhkan dinding pembatas yang telah terbangun. Kelompok Tionghoa inipun mulai membuka diri dan terlibat secara aktif dalam kegiatan kemasyarakatan.

"kalau dulu sangat jarang terlibat, karena dengan adanya "narkoba" dan sebagainya itu yang mulai membuat kita menarik diri, otomatis kan di situ pasti ada premanisme dan sebagainya. 
Nah 98 itu jadi titik balik, kita mulai masuk lagi ke belakang. Setelah itu ya mereka lebih intens terlibat dengan kegiatan masyarakat." (Wawancara A, tokoh agama, 12 September 2019).

\section{Relasi Sosial Warga Sudiroprajan}

Hubungan harmonis kedua kelompok etnis ini mampu meleburkan batasan yang ada menjadi sebuah pembauran dalam keragaman. Pembauran di Sudiroprajan terjadi secara alami baik dalam ruang sosial maupun budaya. Hubungan antar kelompok etnis ini diimplementasikan dalam kehidupan sosial seperti halnya berinteraksi dalam kegiatan masyarakat sehari-hari dalam pertemuan-pertemuan RW, arisan, gotong royong, kerjasama dalam berbagai bidang separti event besar perayaan kemerdekaan Indonesia (17 Agustus), dan lain sebagainya. Masyarakat Sudiroprajan dalam interaksi kegiatan sehari-hari cenderung menggunakan Bahasa Indonesia dan Jawa. Kelompok etnis Tionghoa sendiri sangat jarang menggunakan Bahasa Mandarin dalam berinteraksi, bahkan beberapa diantaranya mengaku tidak bisa dan hanya menggunakan bahasa gaul Mandarin untuk menyebutkan angka-angka China seperti goceng, gopek, dan lain sebagainya. Mereka justru lebih pandai menggunakan Bahasa Jawa bahkan pada level tertinggi seperti krama hinggil (Koentjaraningrat, 1994).

Masyarakat Sudiroprajan terdiri dari dua kelompok etnis berbeda yakni Jawa dan Tionghoa. Kedua kelompok ini telah lama membangun relasi seperti halnya melalui tradisi, budaya, perdagangan, sosial, dan lain sebagainya. Pada perkembangannya kedua kelompok etnis ini saling menerima dan mengakui perbedaan dari masing-masing kelompok. Adanya pengakuan dan penerimaan inilah yang menjadikan kedua kelompok etnis ini menjadi satu kesatuan sebagai masyarakat Sudiroprajan serta membentuk pola hubungan yang stabil. Hubungan stabil tersebut yang kemudian memunculkan adanya kesadaran kolektif dan berimplikasi pada keberagaman masyarakat Sudiroprajan. Keberagaman masyarakat tersebut diakomodasi oleh multikulturalisme yang terbangun melalui kesadaran kolektif dan relasi etnis yang telah lama terbangun. Keberagaman dan kestabilan hubungan dalam masyarakat tersebut yang kemudian membentuk tradisi Grebeg Sudiro sebagai representasi keberagaman dari masyrakat Sudiroprajan. Tradisi Grebeg Sudiro ini juga menampilkan ekspresi budaya dari masing-masing kelompok etnis secara seimbang tanpa adanya dominasi satu sama lain. Gambaran relasi masyarakat Sudiroprajan dapat dilihat dalam gambar 1.

Gambar 1. Pola relasi masyarakat Sudiroprajan

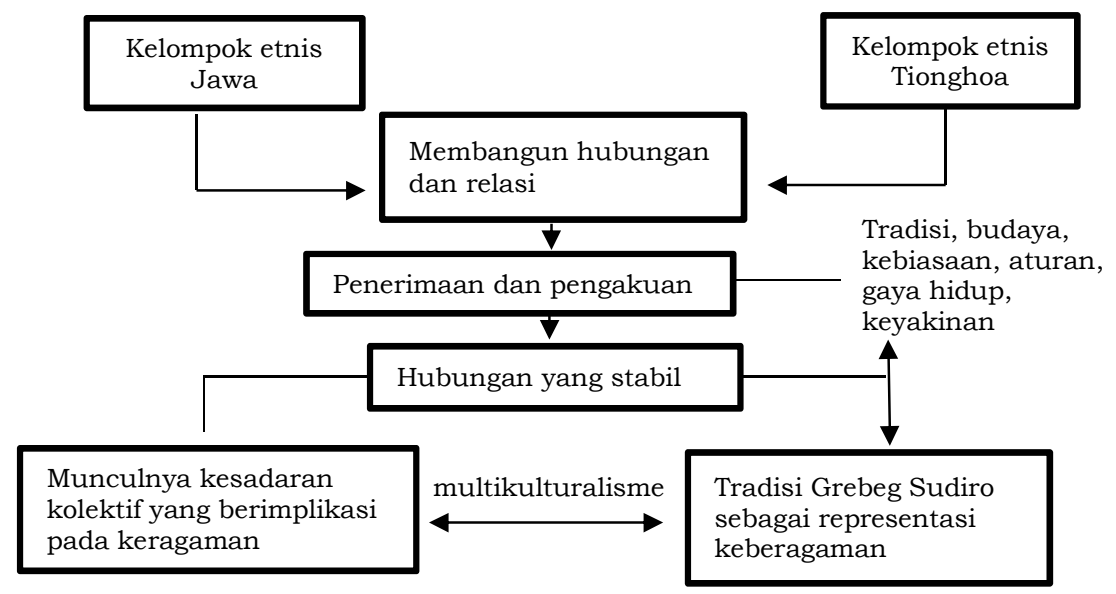

Sumber: Data Primer 2019

Hubungan yang stabil antar kelompok dan adanya pembauran dalam masyarakat secara perlahan juga mengikis adanya stigma terhadap kelompok Tionghoa dan meminimalisir adanya diskriminasi. Orang-orang Tionghoa dalam hal ini turut diberikan kesempatam untuk berpartisipasi secara aktif dalam organisasi kemasyarakatan seperti menjadi ketua RT.

"tidak ada diskriminasi lagi di kampung ini, gak pernah dibedakan berdasar etnis gitu. Gak ada istilah wong Cino wong Jowo. Bahkan di kampung ini dalam beberapa kesempatan orang-ornag 
Tionghoa dijadikan kepala RT atau bahkan ketua organisasi di kampung ini dan itu sampai beberapa periode" (Wawancara L, Tokoh Masyarakat, 14 Juni 2019).

Pembauran juga terlihat dalam konteks budaya. Beberapa diantaranya adalah kesenian Lion Barongsai, Musik Too Kwa Tui Cen, dan Wayang Potehi. Kesenian ini merupakan tradisi dan budaya masyarakat Tionghoa yang masih terjaga hingga saat ini. Pada perkembangannya, kesenian ini tidak hanya dimainkan oleh orang-orang Tionghoa saja, namun juga terbuka peluang bagi orang-orang Jawa untuk turut berpartisipasi memainkannya.

"sekarang ini tradisi dari Cina yang masih dijaga itu liong barongsai. Kalau di sini dikenalnya dengan nama macan putih. Tradisi ini semacam kesenian, yang dulu banyak orang Tioghoa memainkannya. Tapi kemudian banyak orang Jawa juga tertarik mempelajari. Lama-lama sekarang banyak orang Jawa juga turut berpartisipasi ikut main" (Wawancara A, Tokoh Agama, 10 September 2019).

Terjalinnya hubungan antar kelompok ini menyatakan adanya peneriman. Hal ini memungkinkan munculnya kesadaran kolektif untuk berafiliasi satu sama lain dengan unsur-unsur budaya dari kelompok etnis lainnya (Trimble, Dickson, Fisher, \& Lerner, 2005). Kesadaran ini tentunya muncul seiring dengan adanya kepentingan antar individu yang mengubahnya menjadi tindakan sosial nyata seperti toleransi, menghargai perbedaan, dan menerima kondisi multikultur. Selain itu, dalam struktur masyarakat sendiri tidak ada ruang ekslusif yang terbangun. Hubungan antar agama pun sangat cair seperti relasi sosial antar etnik. Hal ini yang turut memperlancar hubungan dan relasi sosial antara kedua kelompok ini. Salah satau bentuk konkrit multikulturalisme pada masyarakat Sudiroprajan adalah dalam kesenian berupa tradisi Grebeg Sudiro. Tradisi ini menjadi salah satu sarana efektif untuk mengkomunikasikan keragaman dan bertukar opini mengenai pembauran (Widyaningsih, 2007).

\section{Representasi Keberagaman dalam Grebeg Sudiro}

Terbukanya ruang dalam kelompok Sudiroprajan ini mampu menghadirkan semangat keberagaman. Semangat ini menjadi suatu upaya dalam merajut kebhinekaan khsusunya dalam masyarakat kampung sendiri. Upaya ini kemudian direalisasikan melalui tradisi Grebeg Sudiro. Tradisi Grebeg Sudiro merupakan tradisi yang memadukan dua unsur budaya kelompok Jawa dan Tionghoa. Grebeg Sudiro terdiri dari dua kata yakni grebeg dan sudiro. Grebeg sendiri sangat lekat dengan budaya Jawa. Grebeg atau garebeg merupakan sebuah tradisi untuk memperingati agenda keagamaan seperti Maulid Nabi Muhammad, 1 Muharram, Idul Fitri dan Idul Adha. Grebeg sendiri rutin diadakan oleh Keraton Surakarta dan Yogyakarta. Sementara nama Sudiro sendiri diambil dari nama kampung Sudiroprajan.

Grebeg Sudiro lahir atas inisiasi dari beberapa tokoh masyarakat di Sudiroprajan sekitar tahun 2007. Pada awalnya grebeg sendiri sempat mengalami adanya penolakan. Penolakan ini dikarenakan beberapa dari mereka masih merasa trauma dengan tragedi masa lalu, peristiwa '98. Meski di kampung Sudiroprajan relatif aman ketika peristiwa tersebut ditambah dengan adanya Keputusan Presiden Republik Indonesia Nomor 6 Tahun 2000 (mengenai pencabutan instruksi presiden mengenai agama, kepercataan dan adat istiadat Cina), tidak lantas membuat mereka berani untuk menunjukkan kebudayaan mereka kepada khalayak umum. Melalui negosiasi tokoh-tokoh berpengaruh di kampung, wacana pembentukan grebeg ini kemudian direalasikan dengan mendapat dukungan penuh dari masyarakat Sudiroprajan.

Tradisi ini kemudian berkembang menjadi event kampung yang dilaksanakan menjelang Tahun Baru Imlek (Adriana, 2013). Grebeg Sudiro pada praktiknya selalu memangkat tema keberagaman dan kebhinekaan. Hal ini dikarenakan grebeg sendiri merupakan representasi dari kelompok Sudiroprajan yang beragam. Keberagaman ini terlihat dalam unsur-unsur budaya dari kedua kelompok etnis ini baik pada saat karnaval dan gunungan, sebagai rangkaian dari acara grebeg tersebut. Adapun unsur-unsur yang dimasukkan ke dalam grebeg ini tidak terdapat adanya dominasi. Budaya keduanya dimasukkan dalam porsi yang sama. Hal ini dilakukan tidak hanya menghindari konflik namun untuk memperkuat nilai keberagaman dan kebhinekaan yang ada.

"dalam pelaksanaan grebeg sendiri kami berusaha untuk memasukkan budaya-budaya secara seimbang. Dulu pernah sempat ada penyanggahan karna terlalu menonjolkan satu sisi, akhirnya kami berusaha untuk mengimbangi dan membagi porsinya. Ini kan event bersama, jadi ya unsur keduanya harus sama" (Wawancara L, Tokoh Masyarakat, 14 Juni 2019). 
Grebeg Sudiro dalam pelaksanaannya tidak bersifat ekslusif, dimana kelompok Tionghoa dan Jawa berbaur baik dalam kepanitiaan atau rangkaian kegiatan lainnya. Pelaksanaan grebeg sendiri juga membuka ruang bagi kelompok etnis lain untuk berpartisipasi dalam rangkaian acara khususnya karnaval. Pada acara kranaval ini, beberapa etnis turut berpartisipasi seperti halnya kelompok dari Kalimantan, Papua, Bali, dan lain sebagainya. Dalam perkembangannya, grebeg yang berawal dari event swadaya masyarakat mulai mendapat perhatian dari pemerintah. Pemerintah dalam hal ini turut mengambil peran dalam kegiatan grebeg seperti halnya memberikan bantuan pendanaan dan promosi. Hal ini terlihat ketika kegiatan Grebeg Sudiro berangusr menjadi semakin besar, pemerintah berinisiatif untuk memasukkannya kedalam kalender event kota Surakarta. Grebeg yang awalnya hanya berskala kampung kini mulai ditonton oleh ribuan orang sebagai salah satu daya tarik wisata kota. Seiring dengan perkembangannya, grebeg turut melakukan perubahan untuk meningkatkan kualitas yang ada. Perubahan dalam pelaksanaan grebeg setiap tahun semakin besar, hal ini terlihat dari yang dulunya hanya kirab gunungan kue keranjang menjadi berbagai ornament yang ditampilkan. Perkembangan ornament yang ditampilkan menjadikan grebeg semakin beragam.

\section{Diskusi}

Kesetaraan dalam masyarakat majemuk diatur oleh sistem sosial yang tergantung pada sifat budaya masing-masing kelompok etnis. Kelompok etnis dalam hal ini berusaha saling melengkpai sehingga mewujudkan suatu ikatan yang positif diantara mereka. Kondisi sifat budaya yang saling melengkapi tersebut memunculkan suatu hubungan yang saling ketergantungan atau membentuk hubungan simbosis. Hubungan antar etnik dan keragaman budaya ini memperlihatkan kondisi dan orientasi nilai dalam klasifikasi kelompok (Barth, 1969).Hubungan simbiosis ini terlihat dalam masyarakat Sudiroprajan. Kelompok Sudiroprajan yang terdiri dari dua kelompok etnis ini mampu membentuk pola hubungan yang stabil. Hubungan yang stabil terbangun dan terjaga jauh sebelum masa kemerdekaan. Seperti yang dijelaskan pada bagian sebelumnya, hubungan dan relasi kedua kelompok etnis ini terjalin melalui beberapa faktor. Adapun faktor yang paling mempengaruhi adalah adanya kesamaan kondisi ekonomi pada masa itu. Kondisi tersebut yang secara tidak langsung membentuk pola hubungan stabil di antara keduanya. Meski demikian, hal ini tentu tidak dapat terlepas dari adanya beberapa potensi konflik yang turut menjadi pondasi dalam membangun pola hubungan stabil pada masyarakat Sudiroprajan.

Potensi konflik yang muncul di Sudiroprajan adalah adanya gap dan batasan-batasan antar kelompok etnis. Gap ini sendiri sempat mewarnai hubungan atau relasi yang stabil dalam masyarakat Sudiroprajan sekitar tahun 1980 hingga 1998. Gap tersebut sebagaimana dijelaskan oleh informan L, membagi masyarakat dalam beberapa sub kelompok diantaranya kelompok Tionghoa pinggiran dan kelompok Tionghoa-Jawa dalam. Orang-orang Tionghoa pinggiran jalan dinilai cenderung tertutup dan membatasi ruang gerak untuk berinteraksi dengan masyarakat dalam kampung. Menurut pemaparan informan A, sebagai orang yang tinggal lama di kawasan pinggir jalan, orang-orang Tionghoa pinggiran banyak yang mempunyai usaha-usaha besar sehingga sangat sukar untuk meluangkan waktu berinteraksi ke dalam kampung. Selain itu, terdapat pula adanya kasus-kasus narkoba yang membuat banyak orang pinggiran tersebut menjadi enggan dan menutup diri dari orang dalam kampung.

Gap tersebut mulai memudar seiring dengan adanya peristiwa '98. Peristiwa tersebut seakan menjadi sebuah peluang untuk membangun kembali keharmonisan relasi antara kelompok Tionghoa pinggiran dengan masyarakat di dalam kampung. Hal ini sebagaimana diutarakan oleh informan A yang melihat hubungan Tionghoa pinggiran berangsur membaik dan mulai membuka diri untuk berpartisipasi secara aktif dalam kegiatan kemasyrakatan. Gap tersebut akhirnya memudar dan tidak ada lagi pelabelan atau pembeda terhadap Tionghoa pinggiran. Gap, kesenjangan, dan konflik pada dasarnya dapat diredam melalui peran dari tokoh masyarakat, termasuk tokoh agama dan etnis dari masing-masing kelompok (Sinaga, 2004). Dinamika relasi antar Tionghoa dan Jawa ini tentunya tidak terlepas dari adanya kerjasama diantara keduanya, khususnya tokoh masyarakat dari masing-masing kelompok (Sinaga, 2004). Tokoh masyarakat dalam hal ini mempunyai peran penting untuk menjaga sinergitas dari kedua kelompok.

Kunci dari terbangunnya relasi harmonis adalah adanya perasaan memiliki, di mana kedua kelompok ini dapat saling menghormati dan menghargai adanya perbedaan. Hal inilah yang membentuk mereka sebagai identitas kolektif yang kuat. Identitas kolektif terjalin 
melalui interaksi, komunikasi dan negosisasi masing-masing etnis dalam kelompok. Terjaganya relasi tersebut juga meminimalisirkan adanya konflik dan prasangka antar kelompok dalam kehidupan sehari-hari. Penerimaan akan perbedaan menjadi salah satu hal yang harus dipenuhi dalam konsep keberagaman atau multikulturalisme. Penerimaan dalam hal ini juga dapat dimaknai sebagai politik pengakuan melalui representasi budaya (Neumannova, 2007). Multikulturalisme sendiri dilihat sebagai sebuah ideologi yang mengakui dan menerima perbedaan dalam kesederajatan (Suparlan, 2001).

Sudiroprajan sebagai masyarakat multikultur tidak pernah menjadikan suatu perbedaan sebagai hambatan. Hubungan antar kelompok dibutuhkan untuk mengurangi kecemasan akan perbedaan dan kecurigaan yang memungkinkan munculnya suatu konflik. Perbedaan di antara kedua kelompok ini dijadikan salah satu upaya untuk menguatkan keberagaman yang telah ada di kampung tersebut. Multikulturalisme di kampung Sudiroprajan sendiri juga diperkuat dengan adanya kesadaran kolektif masyarakat. Mengacu pada penjelasan Kurniawan (2010), basis kesadaran kolektif adalah adanya nilai lokalitas yang terbagi menjadi dua yakni horizontal dan veritkal. Nilai lokalitas horizontal berkaitan dengan normanorma dan keyakinan yang mengatur hubungan antar manusia satu dengan lain, sementara nilai lokalitas vertikal mengacu pada nilai yang mengatur hubungan manusia dengan Tuhan atau sesuatu hal yang mereka (manusia) sucikan. Kesadaran kolektif pada masyarakat Sudiroprajan lebih terlihat melalui nilai-nilai horizontal, di mana tiap anggota masyarakat saling menjunjung tinggi relasi antar kelompok etnis dan menghormati satu sama lain. Adapun implikasi dari adanya nilai lokalitas horizontal ini mengarah pada relasi harmonis antar etnis yang didasarkan hubungan historis dalam masyarakat.

Bagi masyarakat Sudiroprajan, salah satu cara menjaga keharmonisan dalam keberagaman yang ada adalah dengan melibatkan masing-masing anggota kelompok etnis dalam suatu kegiatan kemasyarakatan. Dengan demikian, secara perlahan akan tumbuh rasa saling memiliki sehingga mampu menjaga budaya dan tradisi yang telah ada. Rasa kebersamaan dan saling memiliki tersebut yang kemudian menjadikan masyarakat Sudiroprajan mempunyai keinginan untuk mengekspresikannya dalam ruang publik. Hal tersebut yang kemudian mewujud dalam Grebeg Sudiro. Grebeg Sudiro ini menjadi simbol akan keberagaman dan kesatuan masyarakat Sudiroprajan sekaligus simbol untuk menunjukkan bahwa masyarakat Sudiroprajan ini mempunyai kesadaran kolektif.

Tidak seperti produk budaya lainnya, Grebeg Sudiro dalam hal ini menjadi salah satu sarana efektif untuk mengkomunikasikan multikulturalisme. Hal ini dapat terlihat dalam misi yang dibangun yakni persatuan dengan menyatukan nilai-nilai dari masing-masing kelompok etnis dalam masyarakat Sudiroprajan. Penyatuan ini juga menjadi salah satu upaya menjaga identitas masing-masing kelompok (Fowers \& Richardson, 1996). Masingmasing kelompok dalam hal ini saling berinteraksi dan bernegosiasi dalam ruang sosial yang sama sehingga muncul kesediaan untuk menerima keragaman dan tolera terhadap perbedaan (Budiarti \& Effendy, 2009b). Bagi masyarakat Sudiroprajan, penerimaan ini yang mewujudkan adanya kesadaran kolektif untuk terus melestarikam hubungan yang harmonis antar kedua kelompok. Kesadaran kolektif juga memungkinkan kedua kelompok untuk dapat bernegosiasi ketika terjadi hal-hal yang memicu adanya konflik. Masyarakat dalam hal ini berarti memberikan akomodasi dan melalukan penyesuaian terhadap kelompok lainnya, seperti yang disebut Parekh sebagai multikulturalisme akomodatif (Irhandayaningsih, 2012).

Adanya Grebeg Sudiro dalam bentuk event budaya mampu menjadi salah satu media pembauran antar etnis yang ada dalam amsyarakat Sudiroprajan. Hal ini dikarenakan grebeg merupakan simbol kebersamaan antar etnis yang ada. Tradisi grebeg ini sendiri turut menjunjung kebhinekaan yang tertuang dalam atribut atau simbol dan pertunjukan. Di sisi lain, melalui tradisi grebeg, kegiatan ini mampu menyatukan komunitas-komunitas yang ada untuk menampilkan sesuatu yang dapat dilihat dan dinikmati oleh masyarakat secara umum. Harapan masyarakat dengan adanya event Grebeg Sudiro terbagi menjadi dua, pertama yakni agar grebeg sudiro tidak terlalu kuat menonjolkan simbol salah satu kelompok etnis. Kedua, agar lebih bermanfaat secara ekonomis terhadap kehidupan masyarakat. Namun disisi lain, tetap menciptakan keragaman-keragaman dalam rangkaian acara yang ada.

\section{Kesimpulan}

Keberagaman pada hakikatnya dapat diciptakan melalui suatu wadah yang bisa berawal dari keluarga, lingkungan, kampung hingga ke jenjang berikutnya. Keberagaman tidak hanya berdiri tunggal namun juga harus diperkuat dengan kesadaran kolektif masyarakat 
dan nilai kesadaran bahwa kita hidup beragam entah dalam hal agama, etnis maupun lingkungan. Tentunya kesadaran ini tidak terjalin secara instant melainkan dibangun melalui hidup secara berdampingan dengan perbedaan yang ada pada masing-masing kelompok. Hidup berdampingan antar kelompok etnis inilah yang menciptakan adanya interaksi dan hubungan sosial.

Relasi antar kelompok etnis ini tentu tidak dapat dipisahkan dari proses integrasi yang terjadi dalam masyarakat Sudiroprajan. Integrasi dan pembauran yang terjadi tentunya memiliki implikasi dalam perkembangannya. Pada kasus masyarakat Sudiroprajan, pembauran mampu menghasilkan kesadaran kolektif untuk menghargai dan menerima perbedaan masing-masing kelompok. Kesadaran ini mewujudkan keharmonisan dan semangat multikulturalisme yang direpresentasikan antara lain melalui tradisi Grebeg Sudiro. Tradisi grebeg ini merupakan hasil perpaduan dari dua budaya masing-masing kelompok etnis. Lewat Grebeg Sudiro, ruang keberagaman semakin terbuka seperti halnya membuka peluang bagi kelompok etnis lain untuk berpartisipasi dalam rangkaian acara yang ada.

Tradisi Grebeg Sudiro pada perkembangannya mempunyai implikasi atau dampak yang cukup signifikan bagi masyarakt Sudiroprajan. Adapun dampak dari adanya grebeg terhadap masyarakat Sudiroprajan adalah sebagai berikut 1). Identitas kampung sebagai kampung pembauran semakin terlihat, 2). dianggap sebagai media bagi multikulturalisme, 3). Memperkuat hubungan antar kelompok etnis, dan 4) Menjadi daya tarik pariwisata sehingga meningkatkan perekonomian masyarakat. Masyarakat Sudiroprajan dalam hal ini selalu mengupayakan untuk mempertahankan pelaksanaan Grebeg Sudiro. Beberapa diantaranya adalah perlu adanya evaluasi kegiatan agar tidak ada dominasi dari suatu kelompok maupun etnis yang ada di dalamnya. Komitmen kebersamaan menjadi kunci untuk mempertahankan Grebeg Sudiro.

\section{Ucapan Terima Kasih}

Tulisan ini merupakan bagian dari hasil penelitian tesis penulis yang berjudul Praktik Keberagaman dalam Tradisi Grebeg Sudiro: Studi Pada Kelompok Sudiroprajan Surakarta pada program studi magister Sosiologi, FISIP, Universitas Indonesia. Ucapan terimakasih penulis tujukan kepada masyarakat Sudiroprajan atas segala bentuk bantuan yang diberikan selama proses pengumpulan data penelitian ini. Terimakasih juga penulis sampaikan kepada seluruh pihak yang meluangkan waktu untuk menjadi teman diskusi saya.

\section{Conflicts of Interest}

Penulis menyatakan tidak memiliki conflict of interest antara penulis dengan subjek penelitian dalam penulisan artikel ini.

\section{Daftar Pustaka}

Adriana, T. C. (2013). Tradisi Grebeg Sudiro di Sudiroprajan (Akulturasi Kebudayaan Tionghoa dengan Kebudayaan Jawa). Candi, 1-19.

Baidhawy, Z. (2010). Dinamika Radikalisme dan Konflik Bersentimen Keagamaan di Surakarta. Studia Philosophica et Theologica, 10(2), 258-287. https://doi.org/10.35312/spet.v10i2.91

Barth, F. (1969). ethnic groups and boundaries. boston: little, brown and company.

Budiarti, S. R., \& Effendy, M. A. R. (2009a). Kampung Dunia: Potret Multikulturalisme Bali. (Srti Rahayu Budiarti \& M. A. R. Effendy, Eds.), Departemen Kebudayaan dan Pariwisata. Jakarta: Departemen Kebudayaan dan Pariwisata.

Budiarti, Sri Rahayu, \& Effendy, M. A. R. (2009b). Kampung Dunia: Potret Multikulturalisme Bali. Jakarta: Departemen Kebudayaan dan Pariwisata.

Creswell, J. W. (2015). Penelitian Kualitatif \& Desain Riset Memilih Diantara Lima Pendekatan. Yogyakarta: Pustaka Pelajar.

Firdaus, F., Anggreta, D. K., \& Yasin, F. (2020). Internalizing Multiculturalism Values Through Education Anticipatory Strategies for Multicultural Problems and Intolerance in Indonesia. Jurnal Antropologi: Isu-Isu Sosial Budaya, 01(June), 131-141. https://doi.org/10.25077/jantro.v22.n1.p131-141.2020

Firdaus, F., Yasin, F., \& Anggreta, D. K. (2015). Penanaman Nilai-Nilai Multikulturalisme Melalui Pendidikan Untuk Menyiasati Masalah Multikultur Di Indonesia \& Malaysia. In ASEAN Comparative Education Research Conference (ACER-N 2015) (pp. 1755-1767). 
Fakulti Pendidikan, Universiti Kebangsaan Malaysia.

Fowers, B. J., \& Richardson, F. C. (1996). Why Is Multiculturalism Good? American Psychologist, (June). https://doi.org/10.1037/0003-066X.51.6.609

Hoon, C.-Y. (2006). Assimilation, Multiculturalism, Hybridity: The Dilemmas of The Ethnic Chinese in Post-Suharto Indonesia. Asian Ethnicity, 7(2), 149-166. https://doi.org/ 10.1080/14631360600734400

Irhandayaningsih, A. (2012). Kajian Filosofis Terhadap Multikulturalisme Indonesia. Humanika, 15(9), 1-9.

Joebagio, H. (2017). The Diversity of Surakarta Community: A Blessing toward Democracy. American International Journal of Social Science, 6(1), 16-22.

Juwono, B. (1999). Etnis Cina Di Surakarta 1890-1927: Tinjauan Sosial Ekonomi. Lembaran Sejarah, 2.

Kasturi, T. (2014). Mengelola Keberbedaan Menjadi Sinergi: Pelajaran Dari Sudiroprajan. In A. Supratiknya, Faturochman, \& H. Panggabean (Eds.), Integritas, Keberbedaan \& Kesejahteraan Psikologis: Kontribusi Psikologi dalam Menjawab Tantangan Bangsa Masa Kini (pp. 149-157). Himpunan Psikologi Indonesia (HIMPSI).

Koentjaraningrat, R. M. (1994). Kebudayaan Jawa. Jakarta: Balai Pustaka.

Kumbara, A. A. N. A. (2009). Pluralisme dan Pendidikan Multikultural di Indonesia, IV(7), 531-539.

Kuntowijoyo. (2006). Budaya dan masyarakat. Yogyakarta: Tiara Wacana Yogya.

Kurniawan, H. (2010). Dialogisasi Kesadaran Kolektif dalam Relasi Antarumat Beragama pada Masyarakat Banyumas. Harmoni: Jurnal Multikultural \& Multireligius, IX(36).

Kusumadewi, L. R. (2010). Kembalinya Subyek: Sosiologi Memaknai Kembali Multikulturalisme. Masyarakat: Jurnal Sosiologi, 15(2), 61-84.

Kymlicka, W. (2012). Multiculturalism: Success, Failure, and the Future. Migration Policy Institute.

Liliweri, A. (2005). Prasangka dan Konflik; Komunikasi Lintas Budaya Masyarakat Multikultur. Yogyakarta: LKIS.

Ma'mun. (2005). Kebijakan pemerintah provinsi DKI Jakarta terhadap masyarakat multikultural di DKI Jakarta (1998-2005). Universitas Indonesia.

Neumannova, R. (2007). Multiculturalism and cultural diversity in modern nation state. In Conference Turin. Conference Turin.

Nugroho, I. D. (2011). Majapahit Peradaban Maritim: Ketika Nusantara Menjadi Pengendali Pelabuhan Dunia. Jakarta: Suluh Nuswantara Bakti.

Prihartanti, N., \& Thoyibi, M. (2009). Mengurai Akar Kekerasan Etnis Pada Masyarakat Pluralis. Jurnal Penelitian Humaniora, 10(2), 107-120.

Putro, Y. A., Atmaja, H. T., \& Sodiq, I. (2017). Konflik Rasial Antara Etnis Tionghoa Dengan Pribumi Jawa di Surakarta Tahun 1972-1998. Journal of Indonesian History, 6(1), 6674.

Riyadi, Aji, R. N. B., \& Hermawan, E. S. (2017). Penerimaan Asimilasi Peranakan Tionghoa Surakarta. Analisis Sejarah, 6(1).

Rosado, C. (1996). Toward a Definition of Multiculturalism.

Setyaningrum, A. (2003). Multikulturalisme Sebagai Identitas Kolektif, Kebijakan Politik dan Realitas Sosial. Jurnal Ilmu Sosial Dan Politik, VII(2).

Sinaga, M. L. (2004). Identitas Poskolonial Gereja Suku dalam Masyarakat Sipil: Studi tentang Jaulung Wismaar Siragih dan komunitas Kristen Simalungun. Yogyakarta: LKIS.

Suparlan, P. (2001). Kesetaraan Warga dan Hak Budaya Komuniti dalam Masyarakat Majemuk Indonesia 1, 18-21.

Syaifuddin, A. F. (2006). Membumikan Multikulturalisme di Indonesia. Jurnal Antropologi Sosial Budaya Etnovisi, II(1), 3-11.

Trimble, C. J. E., Dickson, R., Fisher, C. B., \& Lerner, R. M. (2005). Ethnic Identity. In Encyclopedia of applied developmental science (pp. 416-420). https://doi.org/10.4135/9781412950565.n160

Verkuyten, M. (2005). Ethnic Group Identification and Group Evaluation Among Minority and Majority Groups: Testing the Multiculturalism Hypothesis. https://doi.org/10.1037/0022-3514.88.1.121

Widyaningsih, E. D. (2007). Masyarakat "China Balong "Sudiroprajan (Studi Interaksi Sosial Masyarakat China-Jawa di Surakarta pada Pertengahan-Akhir Abad XX ). Universitas Sebelas Maret. 